\title{
Lethal and sublethal effects of sediment burial on the eastern oyster Crassostrea virginica
}

\author{
Allison M. Colden, Romuald N. Lipcius* \\ Virginia Institute of Marine Science, College of William \& Mary, PO Box 1346, Gloucester Point, VA 23062, USA
}

\begin{abstract}
Eastern oysters Crassostrea virginica are dominant ecosystem engineers that construct complex reefs in estuarine systems. Reef persistence relies on reef growth, which must outpace reef degradation and sediment deposition. The quantitative impact of burial on oyster survival and sublethal effects of sediment deposition are undefined. In this mesocosm study, we quantified effects of partial and complete burial $(0,50,70,90$, and $110 \%$ of oyster shell height) on survival, biodeposition, condition index and growth of oysters (shell height $=25-75 \mathrm{~mm}$ ). Survival only declined significantly when $90 \%$ or more of an oyster was buried; the critical burial depth inducing $50 \%$ mortality was $108 \%$. This finding will allow scaling of mortality rates of oysters as a function of sediment load and oyster size. Biodeposition and condition index were negatively related to burial depth, whereas shell growth increased with burial depth. Decreases in biodeposition and condition index were likely related to disruption of feeding by burial and reallocation of energy resources to shell growth. The increase in shell growth was analogous to vertical migration of infaunal species - buried oysters increased vertical shell growth to breach the sediment surface to feed and respire, at the expense of tissue growth. While oysters are tolerant of partial burial in terms of survival, burial adversely affects metabolic processes that influence demographic rates and reef persistence. Future management efforts should consider the effects of partial burial, which often occur more frequently than catastrophic burial events causing mass mortality.
\end{abstract}

KEY WORDS: Sediment $\cdot$ Burial $\cdot$ Mortality $\cdot$ Biodeposition $\cdot$ Oysters $\cdot$ Restoration

\section{INTRODUCTION}

With more than one-third of the world's population living within $100 \mathrm{~km}$ of the coastline (Cohen et al. 1997), the potential for human impacts on coastal and estuarine environments is profound. One such impact is the dramatic increase in terrestrial sediment flux to estuaries as a result of deforestation, land use change, and agriculture (Syvitski et al. 2005). Generally, estuaries act as sediment traps, steadily infilling until an erosional event, such as a strong storm, removes sediment from the system (Dellapenna et al. 1998). Substantial land clearance by European settlers of the US mid-Atlantic region in the late 18th century resulted in a 10-fold increase in sediment inputs to coastal habitats (Meade 1982). Additionally, sediments resulting from this initial land clearance are stored in watershed reservoirs, which are expected to continue to augment sediment inputs for several centuries (Meade 1982). Predicted changes in the frequency and intensity of storm activity, precipitation and streamflow associated with climate change are likely to further increase sediment inputs (Pyke et al. 2008, Najjar et al. 2010) and mobilize watershed sediment stores (Meade 1982). As such, estuaries will continue to experience a constant influx of sediment from exogenous sources.

Sediment inputs influence the structure and function of estuarine habitats through modification of sediment characteristics, nutrient availability, and water clarity. Sediment grain size is an important factor structuring benthic communities (Gray 1981); sediment inputs that significantly alter grain size or bury epifaunal or infaunal organisms can diminish 
benthic diversity and productivity (Maurer et al. 1981). Suspended sediments reduce light availability for estuarine autotrophs; sediment cores from Chesapeake Bay indicate a reduction in microphytobenthos due to reduced water clarity and a shift to pelagic phytoplankton species due to nutrient inputs from run-off after watershed deforestation (Cooper \& Brush 1993). Sediment and nutrient inputs have also been implicated in the widespread reduction in seagrass cover (Orth et al. 2006), with serious consequences for estuarine biodiversity (Waycott et al. 2009).

Like seagrasses, biogenic reefs constructed by the eastern oyster, Crassostrea virginica, are important features structuring the estuarine landscape. Oyster populations and reefs provide a suite of ecosystem services (Coen et al. 2007, Grabowski \& Peterson 2007), such as habitat for benthic macrofauna (Zimmerman et al. 1989), enhanced benthic-pelagic coupling and nutrient cycling (Lenihan 1999, Kellogg et al. 2013), and shoreline stabilization (Meyer et al. 1997, Piazza et al. 2005). Unfortunately, oyster population biomass and associated reef habitat along the Gulf of Mexico and Atlantic coasts in the United States have declined by 88 and $64 \%$, respectively (Zu Ermgassen et al. 2012). Declines in reef quality have been attributed to overharvesting, habitat degradation, and disease (Rothschild et al. 1994). Moreover, the removal of shell material and disassociation of the reef structure by harvesting reduces reef elevation, rendering reefs more susceptible to siltation and eventual burial (Rothschild et al. 1994, Smith et al. 2001).

Reef burial can be caused by episodic events such as storms (Livingston et al. 1999), run-off (Twichell et al. 2010), or dredging (Wilber \& Clarke 2001) whose associated deposition can rival or exceed annual rates (Norris 1953, Miller et al. 2002, Suedel et al. 2014). Winds, waves, and storm surge causes the erosion and mass transport of sediments (Livingston et al. 1999), the deposition of which can kill oysters and bury entire reefs (Norris 1953, Miller et al. 2002, Twichell et al. 2010). Run-off events associated with changes in freshwater inputs to the watershed by precipitation, seasonal inputs, or controlled releases from man-made reservoirs can deposit up to $31 \mathrm{~cm}$ of sediment in a single event (Kniskern \& Kuehl 2003). These events can also bury reefs, particularly those adjacent to river mouths due to their proximity to sediment plumes (Twichell et al. 2010). Additionally, freshwater pulses can cause oyster mortality and exacerbate burial effects. Each year, approximately 400 million $\mathrm{m}^{3}$ of sediment are dredged throughout the United States to maintain channels (Jones \& Lee 1981). Dredged sediments produce a plume that increases suspended sediment concentrations and affects areas up to $500 \mathrm{~m}$ from the dredge site (Wilber \& Clarke 2001, Suedel et al. 2014). Suspended sediments can abrade gill tissues, inflicting metabolic stress (Suedel et al. 2014), and associated deposition may increase oyster mortality by $40 \%$ (Rose 1973).

Despite the presumed importance of sediment deposition on oyster reef persistence (Jordan-Cooley et al. 2011), few studies have addressed burial effects quantitatively and results of those studies have been variable. At the reef scale, sediment deposition has been cited as the main cause of intertidal and subtidal reef failure (Bahr \& Lanier 1981, Taylor \& Bushek 2008, Powers et al. 2009). In contrast, Fodrie et al. (2014) found no correlation between sedimentation and various oyster metrics at a small sub-reef scale $\left(0.25 \mathrm{~m}^{2}\right.$ patches). To elucidate the effects of burial, we experimentally examined the lethal and sublethal effects of sediment deposition on oysters. Specifically, in mesocosm experiments, we (1) quantified survival in various burial depth treatments, (2) determined a critical burial depth at which $50 \%$ of oysters experience mortality $\left(\mathrm{LD}_{50}\right)$, and (3) measured sublethal responses to partial burial by quantifying biodeposition, growth, and condition index. Biodeposition and growth are the key metabolic processes contributing to reef accretion (DeAlteris 1988), which is critical for sustaining reef habitat. Condition index, a ratio of somatic tissue weight to shell cavity volume, is an indicator of oyster health, identifying whether oysters are negatively impacted by burial even if they do not experience mortality. The results of this study can be incorporated into mathematical models (Jordan-Cooley et al. 2011, Wilberg et al. 2013) to determine reef-scale impacts to inform management actions for imperiled eastern oyster populations throughout their geographic range.

\section{MATERIAL AND METHODS}

\section{Mesocosm Expt 1}

We measured survival, growth, condition index, and biodeposition of 278 hatchery-reared triploid oysters over a 28-day period in July 2013. Episodic wind events and spring tidal currents control sediment resuspension and transport in shallow estuarine habitats, indicating that partial or complete burial conditions dominate on time scales of days to weeks (Sanford et al. 1991, Kniskern \& Kuehl 2003). Conse- 
quently, we limited our experiments to the most relevant time frame for deposition in shallow areas, ca. 1 mo, which would encompass spring-neap cycles and episodic events. Triploid oysters were used to minimize individual variation due to reproductive effort and to provide a wide range of sizes of available oysters, given the time of year. Using hatchery oysters from a single source also minimized variation due to differences in acclimation and handling stress, as all oysters were reared in the same area and under the same cultivation methods.

Oysters of 25-75 mm shell height ( $\mathrm{SH}$ ) were obtained from a local oyster grower on the York River, Virginia, and transported to the Virginia Institute of Marine Science in Gloucester Point, Virginia. Shell height $(\mathrm{mm})$ and wet weight $(\mathrm{g})$ were measured for each oyster, and oysters were randomly assigned to one of the following burial treatments: $0,50,70,90$, and $110 \%$. We hypothesized that burial depth relative to the size of the oyster was important; therefore, treatments represented the percentage of an individual oyster's shell height that was buried by sediment (Fig. 1). Oysters in the $0 \%$ burial treatment (control) were placed on top of the sediment.

To ensure proper burial depth and to prevent subsidence of the oyster during the experiment, an individual experimental container $(473 \mathrm{ml})$ with an elevated bottom was prepared for each oyster. Portland cement poured into each container was used to elevate the oyster off the bottom of the experimental container such that the appropriate percentage of the oyster's height given the assigned treatment would be exposed when the container was filled flush with sediment. Each oyster was placed in the prepared container facing upright with the umbo of the oyster resting on the cement bottom (Fig. 1). The containers were filled to the rim with sand (mean $\pm \mathrm{SE}_{\text {; }} 96.6 \pm$ $0.2 \%$ sand) obtained approximately $5 \mathrm{~m}$ offshore of Gloucester Point, Virginia. This sediment grain size typifies sediments in shallow estuarine areas throughout the eastern oysters' geographic range, including the Gulf of Mexico (Lisle \& Comer 2011) and other mid-Atlantic estuaries (Kiddon \& Buffum 2000). Prior to use, sand was sieved with a $500 \mu \mathrm{m}$ sieve to remove debris and defaunated by air-drying.

Experimental containers were distributed evenly into 6 large outdoor mesocosm tanks $(2.43 \times 1.11 \times$ $0.91 \mathrm{~m})$ at the Virginia Institute of Marine Science. Tanks were first divided into 50 even quadrants and containers with oysters were randomly distributed into the quadrants, excluding those directly below the tank inflow and near the tank drain pipe. This distribution ensured even spacing of experimental units throughout the tanks. A downspout was added to the inflow to direct the flow of water towards the bottom of the tank to minimize resuspension of biodeposits collected during the experiment. Tanks were supplied with a continuous flow of unfiltered York River water at a rate of approximately $5.33 \mathrm{l}$ $\min ^{-1}$, resulting in full replacement at least 3 times daily. Aquarium bubblers were added to each tank to ensure adequate oxygenation.

Environmental conditions in the tanks were monitored using data loggers (Tidbit v2 Water Temperature Data Logger, Onset) and a hand-held data sonde (Yellow Springs Instruments). Temperature data to the nearest $0.01^{\circ} \mathrm{C}$ was collected every $30 \mathrm{~min}$ for the duration of the experiment by data loggers. Additional measurements of temperature, salinity, and dissolved oxygen (DO) were periodically taken from the water column at the approximate height of experimental containers using the data sonde to validate the readings from data loggers and to monitor additional environmental variables expected to influence oyster metabolism.

Random samples of oysters in each burial treatment were removed from the tanks at weekly intervals, for a total of 4 sampling events over the $28 \mathrm{~d}$ period. This resulted in 14 replicates per withdrawal-

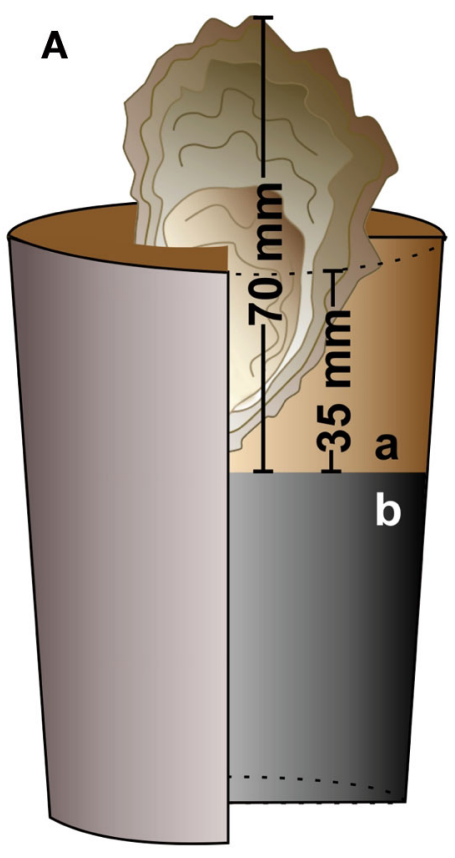

B

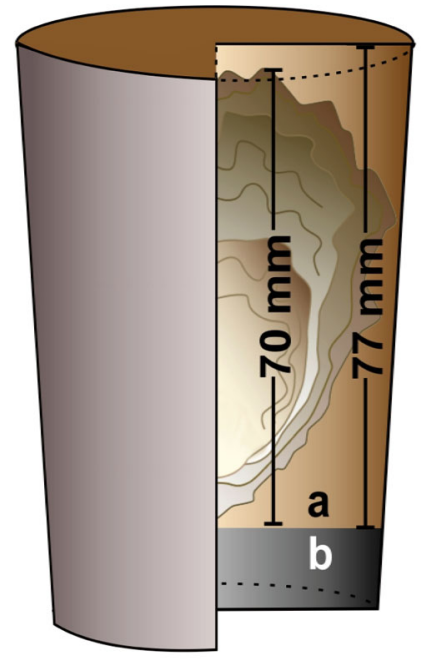

Fig. 1. Set-up of experimental containers. Panel A depicts an oyster in the $50 \%$ burial treatment. Sediment is labeled ' $a$ ' and the elevated bottom of Portland cement is labeled 'b.' Panel B depicts an oyster in the $110 \%$ burial treatment; sediment and elevated bottom are labeled as in Panel A 
treatment combination, with the exception of the $50 \%$-Week 1 and $90 \%$-Week 4 treatments. In these 2 treatment-week combinations, 1 oyster in each was found to be dead prior to the start of the experiment (valves filled with mud), resulting in 13 replicates; the 2 datapoints from these oysters were excluded from all analyses. The subsampled oysters were assessed for survival, growth, and condition index. Biodeposit collection trays were placed on those oysters selected for sampling $6 \mathrm{~d}$ prior to the sampling event. Biodeposits were then collected and processed along with the oysters each week. After removing the oysters, the experimental containers were filled with additional sediment and returned to the mesocosms to avoid changes in flow within the tanks.

\section{Lethal effects}

Oysters were removed from their containers, scrubbed, and visually assessed for survival as follows: live oysters were those whose valves were either tightly closed or closed after handling. Gaping or empty oysters were considered dead. Shell height (mm) and wet weight (g) were measured for all oysters and used to determine growth rates. Live oysters were retained for biodeposition and condition index analyses.

\section{Sublethal effects}

Biodeposits were collected in aluminum trays placed on top of each experimental container. A small slit was cut in the bottom of each collection tray to allow the oyster to protrude through the tray and gape sufficiently, with the exception of collection trays for the $0 \%$ and $110 \%$ treatments for which the tray was left intact. Oysters in the $0 \%$ burial treatment were placed on top of the intact collection tray, which was situated on the sediment surface. Oysters in the $110 \%$ burial treatment did not protrude from the sediment, and the collection tray was placed on top of the oyster on the sediment surface.

After $6 \mathrm{~d}$, collection trays were capped and removed and biodeposits rinsed into pre-weighed dishes. Any biodeposits remaining on the sediment surface in partial burial treatments after the removal of the collection tray were collected by pipette. Biodeposits were easily distinguished from underlying sediments due to their size and pelletized nature. Biodeposits were dried to constant weight at $60^{\circ} \mathrm{C}$ and weighed to the nearest $0.001 \mathrm{~g}( \pm 0.0001 \mathrm{~g})$. Biodeposition rate was calculated as the dry weight (DW) of biodeposits divided by the number of days of biodeposit collection (6 d), expressed as $\mathrm{g} \mathrm{DW}^{-1}$.

Condition index was determined for all live oysters following each sampling event. Oyster condition index was assessed using the index of Abbe \& Albright (2003), the ratio of dry tissue weight ( $g$ ) to shell cavity volume, which is approximated by subtracting the wet weight of the shells immediately after removing oyster tissue from the total wet weight. This condition index accounts for the partitioning of resources into tissue vs. shell growth. Higher condition indices suggest that growth effort is directed toward tissue growth, whereas lower condition indices suggest the dominance of shell growth over tissue growth or the deterioration of tissue quality (weight) over time.

Prior to the start of the experiment and after withdrawal, each oyster's shell height, width, depth, and total wet mass were recorded. Shell height difference was chosen to represent growth rate, as it was the least variable of all growth responses. The difference in shell height before and after the experiment was divided by the number of days in the trial to determine the growth rate in $\mathrm{mm} \mathrm{d}^{-1}$. Oysters with calculated growth rates $<0$ were considered to be 0 , since it is likely that the negative change in shell height was due to measurement error rather than loss of shell at the margin.

\section{Statistical analyses}

Oyster survival was analyzed by logistic regression with burial treatment and time as predictor variables and tank as a blocking factor. Combinations of these variables were used to define the a priori candidate model set (Table 1). Initial analyses of the effect of oyster size on survival indicated that size was not a significant factor $(p=0.56)$; therefore, oyster size was not included as a factor. Akaike's information criterion corrected for small sample size (AICc) was used to compare candidate models (Anderson 2008). Effect sizes and likelihood ratio tests were used to assess model fit. The $50 \%$ mortality level $\left(\mathrm{LD}_{50}\right)$ for burial treatments was determined by solving for the inflection point of the best-fitting logistic model. The $95 \%$ confidence interval for $\mathrm{LD}_{50}$ was determined by bootstrapping $(\mathrm{n}=1000)$ with replacement.

Oyster growth, condition index, and biodeposition rate were analyzed using multiple linear regression, with burial treatment and week as predictor variables and tank as a blocking factor. To account for 
oyster size, an initial regression of size against each response variable was conducted. If oyster size was significant, then the residuals of that regression were analyzed with the candidate model set (Table 1). If size was not significant, then the original data were used in regressions with the candidate model set. We used AIC to select the best model for each response variable. If AIC values indicated more than one plausible model $(w>0.1)$, effect sizes and model fit $\left(\mathrm{r}^{2}\right)$

Table 1. AIC model comparison results for oyster response variables in triploid trials (Expt 1). The best model is indicated in bold. AIC weights $(w)$ indicate the robability of a model representing the best model in the candiate set. pvalues reported for survival models are the result of likelihood ratio tests with the treatment-only model (Model 1) as the null model

\begin{tabular}{|c|c|c|c|c|}
\hline $\begin{array}{l}\text { Survival } \\
\text { Model }\end{array}$ & Parameters & $\mathrm{AICC}$ & $w$ & $\mathrm{p}\left(\chi^{2}\right)$ \\
\hline 1 & Burial & 134.4 & 0.58 & - \\
\hline 2 & Week & 232.9 & $<0.01$ & - \\
\hline 3 & Burial + Week & 136.2 & 0.24 & 0.62 \\
\hline 4 & Burial + Week + Tank & 138.1 & 0.09 & 0.78 \\
\hline 5 & Burial $\times$ Week & 138.3 & 0.08 & 0.87 \\
\hline \multicolumn{5}{|c|}{ Biodeposition } \\
\hline Model & Parameters & $\mathrm{AICC}$ & $w$ & $\mathrm{r}^{2}$ \\
\hline 1 & Burial & 630.1 & $<0.01$ & 0.14 \\
\hline 2 & Week & 558.1 & $<0.01$ & 0.38 \\
\hline 3 & Burial + Week & 503.0 & 0.52 & 0.52 \\
\hline 4 & Burial + Week + Tank & 504.3 & 0.28 & 0.51 \\
\hline 5 & Burial $\times$ Week & 505.0 & 0.20 & 0.51 \\
\hline \multicolumn{5}{|c|}{ Condition index } \\
\hline Model & Parameters & $\mathrm{AICC}$ & $w$ & $\mathrm{r}^{2}$ \\
\hline 1 & Burial & 1102.5 & $<0.01$ & 0.01 \\
\hline 2 & Week & 1007.8 & 0.03 & 0.34 \\
\hline 3 & Burial + Week & 1003.8 & 0.24 & 0.35 \\
\hline 4 & Burial + Week + Tank & 1002.4 & 0.48 & 0.36 \\
\hline 5 & Burial $\times$ Week & 1003.8 & 0.24 & 0.35 \\
\hline \multicolumn{5}{|l|}{ Growth } \\
\hline Model & Parameters & $\mathrm{AICC}$ & $w$ & $\mathrm{r}^{2}$ \\
\hline 1 & Burial & -190.9 & 0.21 & 0.11 \\
\hline 2 & Week & -164.4 & 0.38 & 0.01 \\
\hline 3 & Burial + Week & -191.7 & 0.33 & 0.12 \\
\hline 4 & Burial + Week + Tank & -190.7 & 0.20 & 0.12 \\
\hline 5 & Burial $\times$ Week & -191.3 & 0.26 & 0.12 \\
\hline \multicolumn{5}{|l|}{ Survival } \\
\hline Model & Parameters & $\mathrm{AICC}$ & $w$ & $\mathrm{p}\left(\chi^{2}\right)$ \\
\hline 1 & Burial & 40.2 & 0.69 & - \\
\hline 2 & Size & 50.3 & $<0.01$ & - \\
\hline 3 & Burial + Size & 42.5 & 0.22 & 0.97 \\
\hline 5 & Burial $\times$ Size & 44.3 & 0.09 & 0.72 \\
\hline
\end{tabular}

were examined to determine the most parsimonious model (Anderson 2008). Shapiro-Wilk and Levene's tests and visual inspection of model residuals were used to assess normality and homogeneity of variance assumptions. Biodeposition rate data were logtransformed to meet the assumptions of normality and homogeneity of variance; all other variables satisfied linear regression assumptions without transformation. Differences in environmental variables among tanks were assessed with a 1-way analysis of variance (ANOVA) model. All statistical analyses were conducted using R statistical software, version 3.1.0 (R Core Development Team 2013).

\section{Mesocosm Expt 2}

A second burial trial using wild, diploid oysters collected from the Great Wicomico River, Virginia was conducted to determine if ploidy would affect the burial-survival function. Experimental containers for 56 adult oysters (60-90 $\mathrm{mm} \mathrm{SH})$ were prepared as described previously. Oysters were randomly assigned to $0,25,50,70,90,100$, and $110 \%$ burial treatments $(n=8)$ and randomly distributed into 3 outdoor mesocosm tanks used in the triploid trial. After $12 \mathrm{~d}$, all oysters were removed and assessed for survival. Oysters that were tightly closed or closed upon handling were considered live; gaping oysters that did not respond to handling or empty valves were considered dead. Diploid oysters were expected to experience greater mortality and metabolic stress than triploid oysters due to gametogenesis and reproduction; therefore, diploid trials were shorter than triploid trials. The trial duration (12 d) represents the approximate interval of partial burial due to springneap tidal cycles in the absence of other episodic events. Diploid survival was analyzed using logistic regression and AIC model selection with burial treatment and oyster size as factors (Table 2). Tank and week were not included as factors because no signif-

Table 2. AIC model comparison results for oyster survival in diploid trials (Expt 2). The best model is indicated in bold. pvalues reported are the result of likelihood ratio tests with the treatment-only model (Model 1) as the null model

\begin{tabular}{|lcrrc|}
\hline Model & Parameters & AICc & w & p $\left(\chi^{2}\right)$ \\
\hline $\mathbf{1}$ & Burial & $\mathbf{4 0 . 2}$ & $\mathbf{0 . 6 9}$ & - \\
2 & Size & 50.3 & $<0.01$ & - \\
3 & Burial + Size & 42.5 & 0.22 & 0.97 \\
5 & Burial $\times$ Size & 44.3 & 0.09 & 0.72 \\
\hline
\end{tabular}


icant tank effects were found in previous trials and all oysters were sampled at the conclusion of the $12 \mathrm{~d}$ trial. The diploid burial-survival function was estimated from the best-fitting logistic model, and the point of $50 \%$ mortality $\left(\mathrm{LD}_{50}\right)$ was estimated from the inflection point of the function. The $95 \%$ confidence interval about the inflection point was determined by bootstrapping with replacement $(\mathrm{n}=1000)$.

\section{RESULTS}

\section{Mesocosm Expt 1}

Mesocosm conditions

Temperatures ranged $23.2-36.6^{\circ} \mathrm{C}$, which is well below the maximum thermal tolerance of eastern oysters $\left(48.5^{\circ} \mathrm{C}_{i}\right.$ Shumway 1996$)$. The mean temperature observed in our mesocosms $\left(27.2^{\circ} \mathrm{C}\right.$; Table 3$)$ is within the $15 \mathrm{yr}$ mean temperature range for Virginia $\left(23-29^{\circ} \mathrm{C}\right)$ (Southworth \& Mann 2014) and for other mid-Atlantic estuaries $\left(19-31^{\circ} \mathrm{C}\right)$ (Kiddon \& Buffum 2000). Elevated temperatures $\left(>30^{\circ} \mathrm{C}\right)$ were observed for $<10 \%$ of the experiment's duration, indicating that any effects of thermal stress are likely minimal relative to stress due to burial. The data logger for one tank failed to deploy, and did not collect data for the duration of the experiment; therefore, the temperature data collected by the YSI data sonde was used for comparison. Variation in salinity (17.5-22.4) was also within the tolerance limits of this euryhaline species (Table 3). Dissolved oxygen (DO) levels within experimental tanks remained within normoxic limits throughout the experiment (Table 3), indicating that water column DO levels were sufficient to maintain normal metabolic functions. There were no significant differences between mesocosm tanks in any of the environmental variables (Table 3 ).

Table 3. Summary of environmental conditions in mesocosms for Expt 1. Values given in parentheses are SE. $\mathrm{p}$-values are reported for 1-way ANOVAs for differences in environmental variables between mesocosm tanks

\begin{tabular}{|lrrc|}
\hline Variable & Range & Mean (SE) & p-value \\
\hline Temperature $\left({ }^{\circ} \mathrm{C}\right)$ & $23.2-36.6$ & $27.2(0.1)$ & 0.98 \\
Salinity (ppt) & $17.5-22.4$ & $19.9(0.2)$ & 0.99 \\
Dissolved oxygen $\left(\mathrm{mg} \mathrm{l}^{-1}\right)$ & $3.2-9.3$ & $4.8(0.2)$ & 0.62 \\
\hline
\end{tabular}

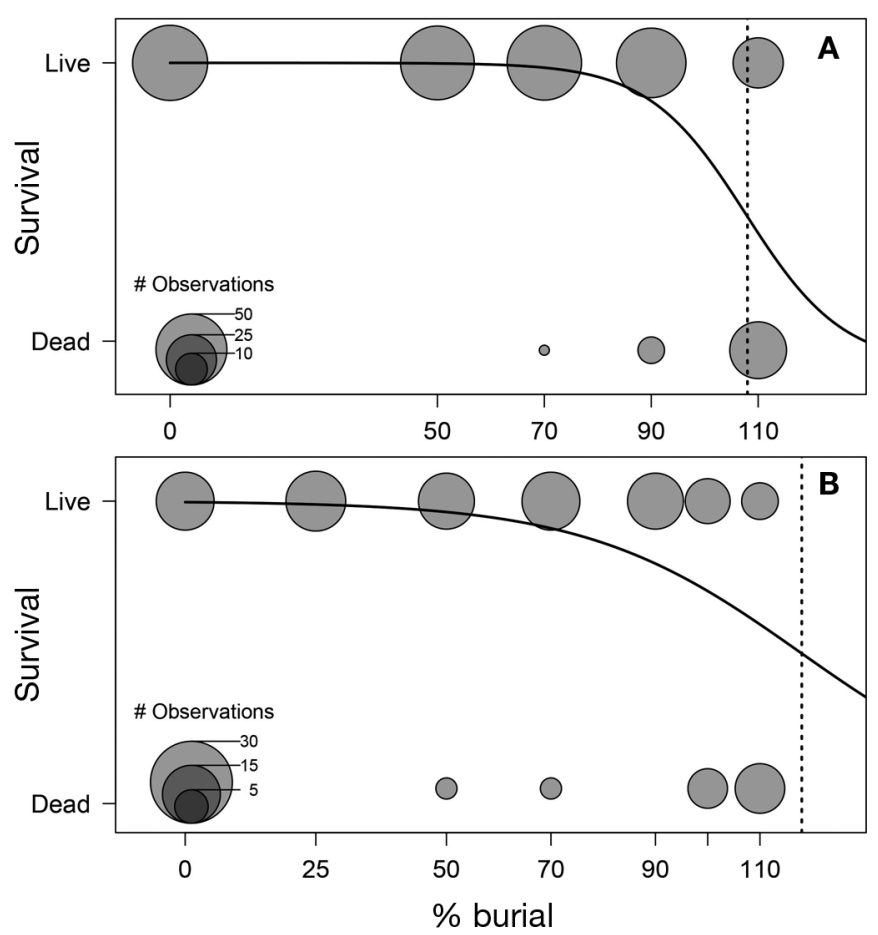

Fig. 2. Oyster survival across \% burial treatments for (A) triploid (Expt 1) and (B) diploid (Expt 2) trials. The size of the circle is proportional to the number of observations at each survival status-treatment combination (smallest circle $=1$ [triploid] or 2 [diploid] observations). Dashed lines indicate the \% burial at which $50 \%$ mortality occurred as estimated from the logistic regression. Burial treatment was the only significant factor (triploid: $p<0.01$; diploid: $p=0.02$ ) for survival

\section{Lethal effects}

The estimated burial-survival function indicated that survival was not significantly impacted by burial up to $70 \%$; the $\mathrm{LD}_{50}$ was $108 \%$ burial (Fig. 2a). In total, 40 oysters died over the course of the experiment, all at burial depths of $70 \%$ and greater (Fig. 2a). The highest mortality occurred in the first week and in the highest burial treatment. Burial treatment was the only significant factor affecting survival (Table 1), and this model provided a significantly better fit than the null (intercept only) model (Wald test, $\mathrm{df}=276, \mathrm{p}<0.01$ ). The remaining models did not improve the fit significantly over the treatment-only model (Table 1).

\section{Sublethal effects}

Biodeposition rate $\left(g \mathrm{DW} \mathrm{d}^{-1}\right.$ ) was highest in the $0 \%$ burial treatment and decreased monotonically 


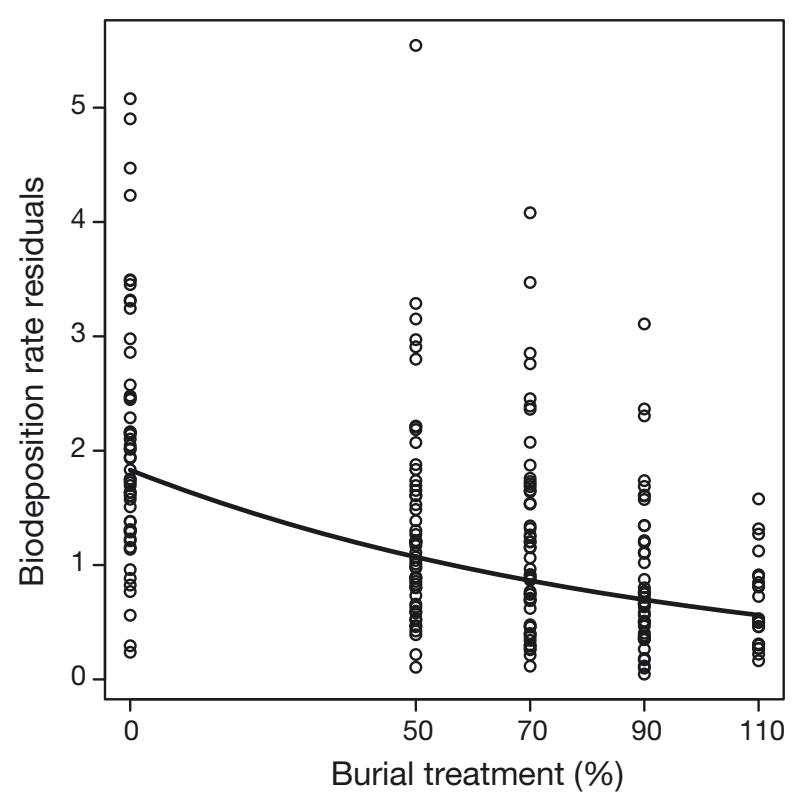

Fig. 3. Biodeposition rate residuals across \% burial treatments in triploid trials (Expt 1). Regression shown is the back-transformed log-linear regression of biodepositionweek regression residuals $\left(\mathrm{r}^{2}=0.22\right)$. Both treatment $(\mathrm{p}<$ $0.01)$ and week $(p<0.01)$ were significant factors controlling biodeposition. Oyster size $(p=0.08)$ and tank $(p=0.40)$ were not significant

and significantly across partial burial treatments (Fig. 3, Table 4). The lowest deposition rate occurred in the $110 \%$ burial treatment (Table 4); however, this value represents passive deposition in the tank rather than biodeposition, as indicated by the absence of fecal pellets. Oysters in the $110 \%$ treatment were entirely buried for the duration of the experiment, and the biodeposit collection trays were situated on the sediment surface within the experimental container. Biodeposition rates in all other treatments (Table 4) may have included some passive deposition, but it was likely minimal because most of the sediment was bound in pseudofeces due to active filtration by oysters. Week was also a significant factor controlling biodeposition rates $(p<0.01)$. Mean biodeposition decreased over time in all burial treatments, indicating increasing metabolic stress over time or temporal changes in seston inputs over the duration of the experiment.

Condition index varied additively with burial treatment and week (Table 1). AIC comparisons indicated that the model including tank effects was the best of the candidate set; however, parameter estimates for tank effects were non-significant $(p=0.07)$, so the treatment-week model, being the most parsimonious, was chosen (our Table 1; Anderson 2008). Bur-
Table 4. Summary of sublethal effects of burial treatments on mean biodeposition, condition index and growth in triploid trials (Expt 1). Values given in parentheses are standard error

\begin{tabular}{|lccc}
\hline $\begin{array}{l}\text { Burial } \\
\text { treatment }(\%)\end{array}$ & $\begin{array}{c}\text { Biodeposition } \\
\left(\mathrm{g} \mathrm{DW} \mathrm{d}{ }^{-1}\right)\end{array}$ & $\begin{array}{c}\text { Condition } \\
\text { index }\end{array}$ & $\begin{array}{c}\text { Growth } \\
\left(\mathrm{mm} \mathrm{d}^{-1}\right)\end{array}$ \\
\hline 0 & $0.27(0.03)$ & $9.8(0.3)$ & $0.12(0.01)$ \\
50 & $0.18(0.03)$ & $9.9(0.5)$ & $0.16(0.02)$ \\
70 & $0.15(0.02)$ & $9.8(0.3)$ & $0.22(0.02)$ \\
90 & $0.11(0.01)$ & $8.9(0.4)$ & $0.24(0.03)$ \\
110 & $0.08(0.01)^{\mathrm{a}}$ & $8.9(0.5)$ & $0.32(0.05)$
\end{tabular}

a Mean deposition reported for $110 \%$ burial treatment represents background sedimentation in the tanks rather than oyster biodeposition

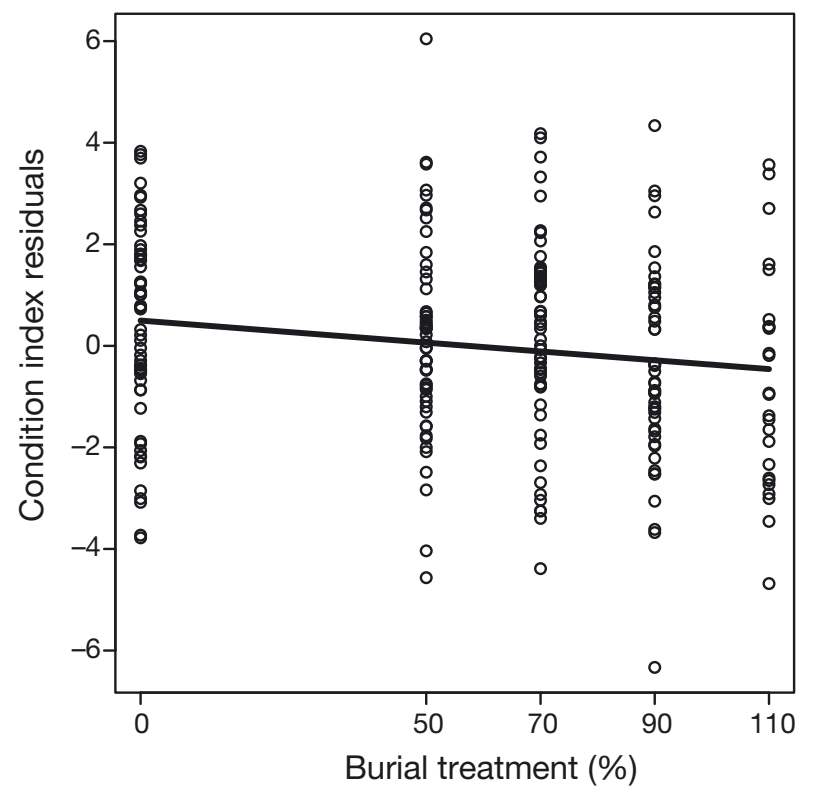

Fig. 4. Oyster condition index across \% burial treatments in triploid trials (Expt 1). Model estimates indicated a significant effect of week on oyster condition index $(\mathrm{p}<0.01)$; therefore, data shown are the residuals from the condition index-week regression as a function of burial treatment $(\mathrm{p}=$ $\left.0.01 ; r^{2}=0.35\right)$. Oyster size $(p=0.15)$ and tank $(p=0.07)$ were not significant

ial treatment and time had opposing effects on oyster condition index. Condition index generally declined with increasing burial (Fig. 4), but increased with time. The highest condition index was in the $50 \%$ burial treatment (Table 4). The 0,50, and $70 \%$ burial treatments tended to have similar condition indices, whereas the 90 and $110 \%$ treatments tended to have lower condition indices (Table 4). Among all burial treatments, the highest condition index was in the $21 \mathrm{~d}$ sampling interval (mean \pm SE: $11.5 \pm 0.2$ ), followed by the $28 \mathrm{~d}$ interval $(11.0 \pm 0.3)$. 


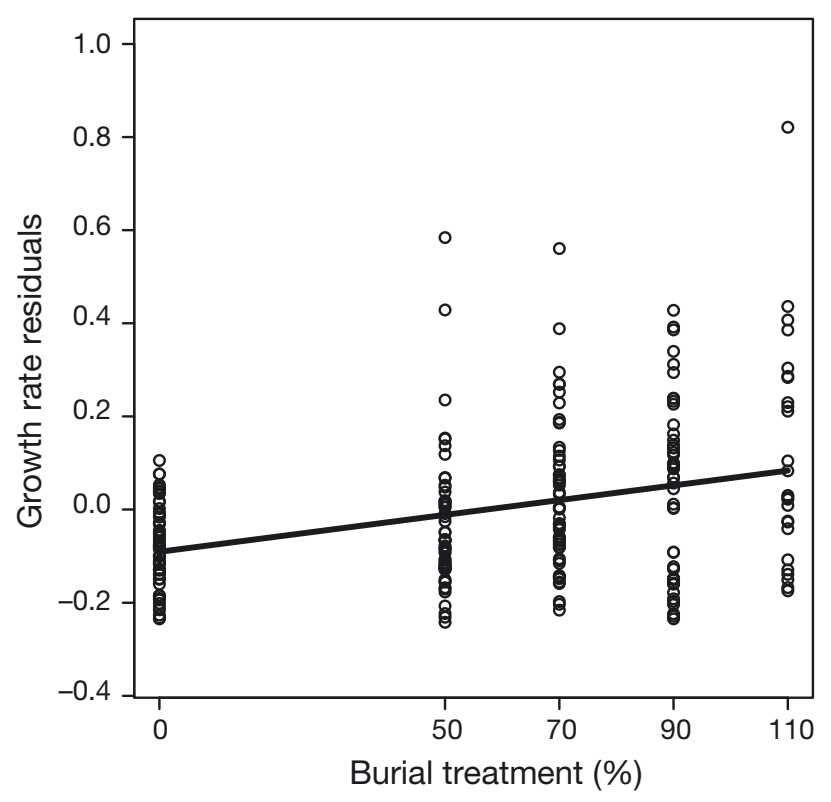

Fig. 5. Oyster growth-rate residuals as a function of \% burial treatment in triploid trials (Expt 1). Initial regression indicated a significant effect of oyster size on growth rate $(\mathrm{p}<$ 0.01); therefore, data shown are the residuals from the sizegrowth rate regression of growth rate as a function of burial treatment $\left(p<0.01 ; r^{2}=0.11\right)$. Tank and week effects were not significant $(p=0.32$ and $p=0.10$, respectively)

Oyster size had a significant effect on growth rates $\left(\mathrm{r}^{2}=0.05 ; \mathrm{p}<0.01\right)$. To account for oyster size, we analyzed the residuals of the oyster size-growth rate linear regression with the candidate model set (Fig. 5, Table 1). Burial treatment was the only significant factor controlling growth rates (Table 1), which increased with burial depth (Fig. 5). The highest growth rate was in the $110 \%$ burial treatment, which was nearly 3 times the mean growth rate of the $0 \%$ burial treatment (Table 4). Mean growth rates in 70 and $90 \%$ burial treatments were double the growth rate of the $0 \%$ treatment (Table 4 ).

\section{Mesocosm Expt 2}

After $12 \mathrm{~d}, 8$ of 56 oysters in the diploid trial died, which occurred in the 50, 70, 100 and $110 \%$ burial treatments. The highest mortality was in the $110 \%$ burial treatment $(\mathrm{n}=5)$, and was equivalent in the 50, 70 , and $100 \%$ treatments in which a single oyster died. No mortality was observed in 0,25 , or $90 \%$ treatments. As in the triploid trials, burial treatment was the only significant factor affecting survival (Table $2, p=0.023$ ); oyster size and treatment-size in- teractions were not significant $(p=0.44$ and $p=0.41$, respectively). The treatment only model provided a significantly better fit than the null model (Wald test; $\mathrm{df}=2 ; \mathrm{p}=0.001$ ) and the additive and interaction models were not significantly different from the treatment model (Fig. 2b, Table 2). The diploid burial-survival function (Fig. 2b) had an estimated inflection point of $118 \%$ burial (95\% CI: $96-154 \%$ ), which is higher than the $\mathrm{LD}_{50}$ for triploids of $108 \%$.

\section{DISCUSSION}

The key findings of our study were that (1) oysters buried in sediment did not exhibit significant mortality or sublethal effects until at least $70 \%$ of the shell was buried, (2) the survival response differed little between diploid and triploid oysters or by oyster size, (3) biodeposition and condition index were inversely related to burial depth, and (4) shell growth increased with burial depth.

\section{Lethal effects}

With the exception of 1 oyster in the $70 \%$ burial treatment, all mortality occurred in the 90 and $110 \%$ burial treatments over the $28 \mathrm{~d}$ experiment. The maximum mortality was $62 \%$ during the first week in the $110 \%$ treatment group, although oyster survival did not vary significantly with time. This mortality was much lower than those observed previously (Lund 1957a, Dunnington 1968), in which $100 \%$ mortality of completely buried adult oysters occurred within $7 \mathrm{~d}$. However, the burial depths in previous experiments were higher, up to $76 \mathrm{~mm}$ of sediment (Dunnington 1968). In experiments with comparable burial depths, lethal burial depths for adult oysters were 10-20 mm below the sediment surface (Kranz 1974, Essink 1999), though these values were not calculated relative to shell height. The maximum burial depth in the present study was $7.4 \mathrm{~mm}$ for a $73.5 \mathrm{~mm}$ oyster. Lund (1957a) suggested that shallowly buried oysters $(<12.7 \mathrm{~mm})$ may be able to clear sediment from their bill by repeatedly opening and closing their valves, a behavioral adaptation to burial. Exposed valves were not observed in any of the $110 \%$ burial treatments; however, small depressions in the sediment surface were evident, which may indicate the movement of buried oysters in an attempt to remove sediment (Lund 1957a, Hinchey et al. 2006).

Diploid and triploid oysters responded similarly to burial, with the highest mortality observed in the 
complete (110\%) burial treatments (Fig. 2). Diploid oysters exhibited mortality at lower partial burial $(50 \%)$ than triploids $(70 \%)$, but mortality in the $50 \%$ diploid treatment was limited to a single oyster. The $\mathrm{LD}_{50}$ for diploids was $118 \%$ burial, which is higher than the $108 \% \mathrm{LD}_{50}$ for triploids (Fig. 2); however, these estimates were not significantly different from one other, suggesting that both triploids and diploids are tolerant to partial burial in terms of survival. The higher $\mathrm{LD}_{50}$ for diploids may have resulted from a shorter experimental duration or the larger size of oysters used in diploid trials. Diploid trials were limited to $12 \mathrm{~d}$, whereas triploid trials lasted up to $28 \mathrm{~d}$. A longer trial duration for triploids may have led to exhaustion of metabolic reserves under non-feeding, anaerobic conditions leading to higher mortality rates and an associated decrease in the estimated $\mathrm{LD}_{50}$. Additionally, diploid oysters were collected from the wild and were larger (60-90 $\mathrm{mm} \mathrm{SH}$ ) than triploids (25-75 mm SH). Although physiological studies suggest that larger oysters are better suited to survive anoxic conditions due to larger capacity for carbohydrate storage, which is catabolized in anaerobic pathways (de Zwaan \& Wijsman 1976), we detected no effects of oyster size on survival in either triploid or diploid trials. Overall, both diploid and triploid oysters were tolerant to partial burial and responded similarly to burial regardless of ploidy, which reaffirms the findings of a previous study on the lack of an effect of ploidy on oyster survival (Walton et al. 2013).

Oyster size did not have a significant effect on survival, which was unexpected. Under the anaerobic conditions of burial, oysters revert to catabolism of carbohydrates to maintain metabolic function (de Zwaan \& Wijsman 1976). The ability of oysters to carry out anaerobic metabolism increases with developmental stage, as body size and the capacity for carbohydrate storage increases (Widdows et al. 1989); thus, we expected that juvenile oysters would experience higher mortality due to burial than adult oysters. Kranz (1974) also observed no size effects on survival for buried $C$. virginica, purple-hinge rock scallops (Hinnites multirugosus), which similarly adhere to hard surfaces, and bay scallops (Aequipecten irradians), whereas larger individuals of 2 mussel species (Modiolus demissus and Mytilus edulis) did survive better than smaller individuals. Others have documented effects of burial and anaerobic metabolism on juvenile $C$. virginica $(16 \mathrm{~mm} \mathrm{SH}$, Widdows et al. 1989; 9-12 mm SH, Hinchey et al. 2006), but did not examine size effects. The fact that oysters in this study did not differ in survival suggests that neither the capacity for glycogen storage facili- tated by larger body size nor the ability to physically ventilate the sediment to relieve sediment overburden were driving factors in survival.

Conversely, if we assume that oyster mortality increases significantly at burial depths $>110 \% \mathrm{SH}$, then smaller oysters would experience significantly higher mortality at absolute sediment loads that would not affect larger oysters appreciably. For instance, a $6 \mathrm{~mm}$ sediment load should cause relatively low mortality (about $40 \%$ ) in adult oysters of $100 \mathrm{~mm} \mathrm{SH} \mathrm{(106 \%} \mathrm{burial),} \mathrm{whereas} \mathrm{the} \mathrm{same} 6 \mathrm{~mm}$ load should cause $100 \%$ mortality in juvenile oysters $\leq 20 \mathrm{~mm} \mathrm{SH}$ ( $\geq 130 \%$ burial). A major benefit of our findings is therefore that it will allow scaling of mortality rates of oysters as a function of sediment load and oyster size.

Epifaunal and infaunal species demonstrate varying degrees of tolerance to burial, based on their response to metabolic stress and life history strategy (Kranz 1974, Maurer et al. 1981, Hinchey et al. 2006). Motile infaunal bivalves are generally better suited than epifaunal bivalves to escape burial by vertical migration and siphon extension. Mortality of the infaunal bivalves Mercenaria mercenaria and $\mathrm{Nu}$ cula proxima increased with burial depth and burial time (Maurer et al. 1981); however, M. mercenaria were able to overcome more than $16 \mathrm{~cm}$ of burial by vertical migration (Maurer et al. 1981). Epifaunal suspension feeders, such as oysters and mussels, are more susceptible to burial due to their sessile life history and lack of a digging foot (Kranz 1974, Hinchey et al. 2006). Overall, low mortality rates in the present study indicate that oysters are highly tolerant to partial and shallow total burial on weekly time scales, more so than other epifaunal suspension feeders (Maurer et al. 1981, Hinchey et al. 2006).

\section{Sublethal effects}

Biodeposition was inversely related to partial burial depth. The sediment collected in the $110 \%$ treatment represented background deposition within the mesocosms, since oysters neither penetrated the sediment surface nor produced fecal pellets in that treatment. Similarly, no biodeposition was observed for juvenile oysters (9-12 $\mathrm{mm} \mathrm{SH}$ ) buried in 2-5 $\mathrm{mm}$ of silty sand (Hinchey et al. 2006). Biodeposition rates in 0-90\% burial treatments were 1.4-3.4-fold greater than background sediment deposition (110\%). Mean biodeposition in the unburied $(0 \%)$ treatment $(0.27 \mathrm{~g}$ DW $\mathrm{d}^{-1}$ ) was comparable to values in previous studies (0.1-0.2 $\mathrm{g} \mathrm{DW} \mathrm{d}^{-1}$; Haven \& Morales-Alamo 1966, 
1972). Although biodeposition was reduced in the 50 and $70 \%$ treatments $\left(0.15-0.18 \mathrm{~g} \mathrm{DW} \mathrm{d}^{-1}\right)$, it also fell within normal ranges of biodeposition for oysters not subjected to burial (Haven \& Morales-Alamo 1966).

We did not observe significant effects of oyster size on biodeposition. In contrast, Haven \& MoralesAlamo (1972) found that biodeposition rate increased asymptotically with oyster size, though the rate per unit weight of oyster decreased with increasing oyster size. The difference in response may be due to the different sizes of oysters used in the 2 studies, or due to our use of triploid oysters. Diploid oysters experience additional metabolic stress relative to triploids during spawning periods (Dégremont et al. 2012), and reproductive effort in oysters scales with oyster size (Thompson et al. 1996); therefore, diploid oysters are more likely to exhibit a size-specific response to external stressors than are triploids.

Biodeposition is a critically important process contributing to reef sustainability (DeAlteris 1988) and modulating sediment supply on and around reefs (Widdows et al. 1998). Oyster biodeposits are composed primarily of small inorganic particles with very slow settling velocities. The repackaging of these suspended sediments by oysters into feces and pseudofeces increases the settling velocity and cohesiveness of the sediment, leading to rapid deposition (Haven \& Morales-Alamo 1966, 1972, DeAlteris 1988). In areas where bivalves occur, biodeposition accounts for as much as $25 \%$ of all deposition, and the rate of sediment delivery via biodeposition can be 8-fold higher than gravitational settling (Lund 1957a).

Long-term subtidal oyster reef persistence is determined by a balance between sediment accumulation, reef accretion, and sea level rise (DeAlteris 1988). Biodeposits contribute to reef accretion by filling reef interstitial space, effectively elevating the reef surface. Biogenic sediments (biodeposits and shell) on subtidal reefs accumulate as quickly as $50 \mathrm{~cm}$ per 100 y (DeAlteris 1988). Maximum sea level rise estimates for the mid-Atlantic region are $20-29 \mathrm{~cm}$ by 2100 (Sallenger et al. 2012), indicating that subtidal oyster reefs should outpace sea level rise given ideal conditions for accretion, similarly to intertidal reefs (Rodriguez et al. 2014). In the absence of biodeposits, caused either by reduced biodeposit production or erosion, reef accretion depends solely on the addition of shell through oyster recruitment and mortality, the rate of which may be less than the current rate of sea level rise (DeAlteris 1988). Intertidal reefs experience similar depositional events due to shifting sediments and storms (Taylor \& Bushek 2008), but the effects of these events may be exacerbated by reduced erosion due to lack of inundation, leading to further reductions in accretion on intertidal reefs relative to subtidal reefs. Thus, the reduction in biodeposit production associated with partial burial observed in this study suggests that non-catastrophic burial events can have lasting impacts on long-term oyster reef persistence even in the absence of mass mortality.

Condition index decreased significantly with increased burial depth. Oysters in the control treatment (0\% burial) had the highest condition index, indicating a higher tissue-to-shell ratio in these oysters than those in other treatments. The decline in condition index with burial depth could be indicative of either the deterioration of tissue due to metabolic stress and sustained anaerobic conditions or to the investment of energy into shell growth when access to food and oxygen are limited by burial. In contrast, high suspended-sediment loads had little effect on oyster condition index after 7 d (Suedel et al. 2014), indicating that sediment deposition and burial are more detrimental to oyster condition index than are high suspended-sediment loads.

Shell growth was influenced by oyster size and burial treatment. Maximum growth rates were in the $110 \%$ burial treatment $\left(0.32 \pm 0.05 \mathrm{~mm} \mathrm{~d}^{-1}\right)$, which is higher than the growth rate for triploid $C$. virginica under normal conditions (0.2 $\mathrm{mm} \mathrm{d}^{-1}$; Harding 2007). In addition, mean growth rates of the 70,90 , and $110 \%$ treatments $\left(0.22-0.32 \mathrm{~mm} \mathrm{~d}^{-1}\right)$ exceeded previously published growth rates $\left(0.1-0.2 \mathrm{~mm} \mathrm{~d}^{-1}\right)$ for both diploid and triploid C. virginica (Harding 2007, Kraeuter et al. 2007, Dégremont et al. 2012, Walton et al. 2013). Growth rates for the 0 and $50 \%$ burial treatments (0.12-0.16 $\left.\mathrm{mm} \mathrm{d}^{-1}\right)$ agreed well with published estimates.

The effect of partial burial on oyster growth has not previously been addressed, but sediment deposition has been shown to negatively affect oyster growth (Grant et al. 1990, Lenihan 1999). Accelerated growth in shell height of oysters has been recorded in response to high-density conditions, which produces long and narrow oysters with shells up to $36 \mathrm{~cm}$ long (McCormick-Ray 2005). Under resource competition, oysters grow in the vertical axis to reach phytoplankton higher in the water column. Additionally, oysters in muddy habitats, which are often found almost completely buried, also exhibit an elongated shape, a presumed adaptation to rapidly accumulating soft sediments (Galtsoff \& Luce 1930, Chinzei 1986). This life history may represent a trade-off by which oysters are subjected to enhanced sedimentation but avoid shell-boring polychaetes and sponges, which cannot survive anoxic sediments (Carver et al. 2010). 
We suspect that oysters experiencing stress caused by partial or complete burial exhibit a similar vertical growth response to reach the sediment surface to feed and respire.

That the highest growth rate and lowest condition index were in the $110 \%$ treatment suggests that decreases in condition index were more likely due to oyster responses to burial than deterioration of tissues under anoxic conditions. We surmise that oysters responded to sediment burial by allocating energy reserves to shell growth in an attempt to remain above the sediment surface. This response would be comparable to vertical migration behavior by clams buried by sediment (Maurer et al. 1981). Seagrasses also exhibit a similar response, in which buried shoots increase vertical growth in response to moderate burial (Marbà \& Duarte 1994, Cabaço et al. 2008). In oysters, this may represent a physiological response to accumulating biodeposits, in which oysters allocate resources to vertical growth. Oysters usually live in constant contact with biodeposits, which can accumulate rapidly and produce anoxic, reducing conditions similar to those below the sediment surface (Lund 1957b). The monotonic increase of growth rate with increasing burial suggests that this growth response was triggered before total burial and may serve as an important mechanism for oysters to outpace sediment accumulation. Growth rates were highest under complete burial, indicating that the likely limit to this increased growth is burial that induces mass mortality. Extrapolations from the estimated burial-survival function suggest that mass mortality occurs at approximately $130 \%$ burial.

The use of hatchery-reared triploid oysters in this experiment allowed for control of individual variation, but it precludes precise application of our observations of sublethal burial effects to wild, diploid oysters. Our results indicated no significant difference between triploid and diploid oysters with respect to survival. This may suggest that diploid oysters would respond similarly in sublethal effects, but previous studies indicate triploid oysters grow faster and have higher condition indices than diploid oysters under field conditions (Walton et al. 2013). Thus, our shell growth rates and condition indices are likely to overestimate those of diploid oysters (Walton et al. 2013), but we expect the observed trends to hold.

\section{CONCLUSIONS}

The impacts of sediment deposition on estuarine habitats, particularly biogenic habitats, are expected to increase with climate change. Amplification in storm frequency and intensity will increase the likelihood of mass transport of sediment that can cause rapid deposition events (Najjar et al. 2010). Increases in precipitation intensity are likely to mobilize stored sediments and magnify sediment inputs to estuaries (Meade 1982, Najjar et al. 2010), while sea-level rise will increase available accommodation space and enhance coastal erosion due to changes in estuary volume and tidal currents (Short \& Neckles 1999). Sediment inputs affect water clarity, nutrient availability, and sediment characteristics, all of which impact species' distributions and estuarine productivity. Overall, the impacts of sediment deposition and burial on biogenic habitats are likely to increase over time, indicating that a clear understanding of the response of oyster reefs to short- and long-term burial events is needed.

The findings of our study can improve population model predictions by accounting for sublethal impacts of burial and episodic events that may impact reef persistence. These predictions may be used to inform reef placement or construction criteria to minimize adverse effects of partial burial on reef-building processes, particularly biodeposition. This study indicated that oysters can survive burial up to $70 \%$ of their shell height, but that sublethal effects of burial on biodeposition, growth, and condition index may occur at lower levels of partial burial. Oyster metabolic processes contribute to the growth of oyster reefs over time through reproduction, growth, and the production of biodeposits (DeAlteris 1988). These reef-building processes help maintain ideal reef conditions by elevating the reef off the bottom to heights where oysters experience reduced sedimentation, higher survival, and faster growth (Lenihan 1999). Understanding the impacts of sediment burial on oyster survival and function is critical to the success of continued restoration efforts, the recovery of natural oyster populations, and the productivity of aquaculture operations. This study demonstrates that burial of oysters by sediment, even partially, can impact the sustainability of natural and man-made oyster reefs by impairing reef-building processes.

Acknowledgements. We thank Goodwin Island Oyster Company (T. McCulloch and D. McCulloch) for providing oysters used in the experiment, M. Seebo for set-up and maintenance of the flow-through systems, and C. Seppi for conduct of the experiment and processing of oysters while completing an NSF-REU internship. We thank R. Seitz, M. Reidenbach, C. Peterson, and 3 anonymous reviewers for helpful comments that improved this manuscript. Funding for this research was provided by NSF Grants REU OCE-1062882 and Mathematical Biology DMS-1313093. A.M.C. also received 
support from NSF GK-12 (DGE-0840804). This paper is Contribution No. 3431 of the Virginia Institute of Marine Science, College of William \& Mary.

\section{LITERATURE CITED}

Abbe GR, Albright BW (2003) An improvement to the determination of meat condition index for the Eastern Oyster Crassostrea virginica (Gmelin 1791). J Shellfish Res 22: 3747-3752

Anderson DR (2008) Model based inference in the life sciences. Springer Science Press, New York, NY

Bahr LM, Lanier WP (1981) The ecology of intertidal oyster reefs of the South Atlantic coast: a community profile. US Fish and Wildlife Service, Washington, DC

> Cabaço S, Santos R, Duarte CM (2008) The impact of sediment burial and erosion on seagrass: a review. Estuar Coast Shelf Sci 79:354-366

> Carver CE, Théiault I, Mallet AL (2010) Infection of cultured eastern oysters Crassostrea virginica by the boring sponge Cliona celata, with emphasis on sponge life history and mitigation strategies. J Shellfish Res 29:905-915

Chinzei K (1986) Shell structure, growth, and functional morphology of an elongate cretaceous oyster. Palaeontology 29:139-154

> Coen LD, Brumbaugh RD, Bushek D, Grizzle R and others (2007) Ecosystem services related to oyster restoration. Mar Ecol Prog Ser 341:303-307

Cohen JE, Small C, Mellinger A, Gallup J, Sachs J, Vitousek PM, Mooney HA (1997) Estimates of coastal populations. Science 278:1211-1212

> Cooper SR, Brush GS (1993) A 2500-year history of anoxia and eutrophication in Chesapeake Bay. Estuaries 16: $617-626$

de Zwaan A, Wijsman TCM (1976) Anaerobic metabolism in bivalvia (Mollusca): Characteristics of anaerobic metabolism. Comp Biochem Physiol B 54:313-324

DeAlteris JT (1988) The geomorphic development of wreck shoal, a subtidal oyster reef of the James River, Virginia. Estuaries 11:240-249

> Dégremont L, Garcia C, Frank-Lawale A, Allen SK (2012) Triploid oysters in the Chesapeake Bay: comparison of diploid and triploid Crassostrea virginica. J Shellfish Res 31:21-31

- Dellapenna TM, Kuehl SA, Schaffner LC (1998) Seabed mixing and particle residence times in biologically and physically dominated estuarine systems: a comparison of lower Chesapeake Bay and the York River subestuary. Estuar Coast Shelf Sci 46:777-795

Dunnington EA (1968) Survival time of oysters after burial at various temperatures. Proc Natl Shellfish Assoc 58: 101-103

Essink K (1999) Ecological effects of dumping of dredged sediments; options for management. J Coast Conserv 5: 69-80

Fodrie FJ, Rodriguez AB, Baillie CJ, Brodeur MC and others (2014) Classic paradigms in a novel environment: inserting food web and productivity lessons from rocky shores and saltmarshes into biogenic reef restoration. J Appl Ecol 51:1314-1325

Galtsoff PS, Luce RH (1930) Oyster investigations in Georgia. Bureau of Fisheries Document 1077, Appendix V. Report of the United States Commissioner of Fisheries for 1930, p 61-100
Grabowski JH, Peterson CH (2007) Restoring oyster reefs to recover ecosystem services. In: Cuddington $\mathrm{K}$, Byers JE, Wilson WG, Hastings A (eds) Ecosystem engineers: plants to protists. Elsevier Academic Press, Burlington, MA, p 281-298

Grant J, Enright CT, Griswold A (1990) Resuspension and growth of Ostrea edulis: a field experiment. Mar Biol 104: $51-59$

Gray JS (1981) The ecology of marine sediments: an introduction to the structure and function of benthic communities. Cambridge University Press, New York, NY

Harding JA (2007) Comparison of growth rates between diploid DEBY eastern oysters (Crassostrea virginica, Gmelin 1791), triploid eastern oysters, and triploid Suminoe oysters (C. ariakensis, Fugita 1913). J Shellfish Res 26:961-972

> Haven DS, Morales-Alamo R (1966) Aspects of biodeposition by oysters and other invertebrate filter feeders. Limnol Oceanogr 11:487-498

Haven DS, Morales-Alamo R (1972) Biodeposition as a factor in sedimentation of fine suspended solids in estuaries. Geol Soc Am Bull 133:121-130

- Hinchey EK, Schaffner LC, Hoar CC, Vogt BW, Batte LP (2006) Responses of estuarine benthic invertebrates to sediment burial: the importance of mobility and adaptation. Hydrobiologia 556:85-98

Jones RA, Lee GF (1981) The significance of dredging and dredged material disposal as a source of nitrogen and phosphorus for estuarine waters. In: Neilson BJ, Cronin LE (eds) Estuaries and nutrients. Humana Press, Clifton, NJ, p 517-530

> Jordan-Cooley WC, Lipcius RN, Shaw LB, Shen J, Shi J (2011) Bistability in a differential equation model of oyster reef height and sediment accumulation. J Theor Biol 289:1-11

Kellogg ML, Cornwell JC, Owens MS, Paynter KT (2013) Denitrification and nutrient assimilation on a restored oyster reef. Mar Ecol Prog Ser 480:1-19

Kiddon J, Buffum H (2000) Sediment characteristics data: Mid-Atlantic Integrated Assessment. U.S. Environmental Protection Agency www.epa.gov/emap/maia/html/data/

Kniskern TA, Kuehl SA (2003) Spatial and temporal variability of seabed disturbance in the York River subestuary. Estuar Coast Shelf Sci 58:37-55

> Kraeuter JN, Ford S, Cummings M (2007) Oyster growth analysis: a comparison of methods. J Shellfish Res 26: 479-491

Kranz PM (1974) The anastrophic burial of bivalves and its paleoecological significance. J Geol 82:237-265

Lenihan HS (1999) Physical-biological coupling on oyster reefs: how habitat structure influences individual performance. Ecol Monogr 69:251-275

Lisle JT, Comer NN (2011) Characterization of sediments from the Gulf of Mexico and Atlantic shorelines, Texas to Florida. US Geological Survey Open-File Report 20111199. USGS, Reston, VA, http://pubs.usgs.gov/of/2011/ 1199/

Livingston RJ, Howell RL, Niu X, Lewis FG, Woodsum GC (1999) Recovery of oyster reefs (Crassostrea virginica) in a Gulf estuary following disturbance by two hurricanes. Bull Mar Sci 64:465-483

Lund EJ (1957a) Self-silting by the oyster and its significance for sedimentation geology. Institute of Marine Science, University of Texas, Port Aransas, TX

Lund EJ (1957b) Self-silting, survival of the oyster as a 
closed system, and reducing tendencies of the environment of the oyster. Institute of Marine Science, University of Texas, Port Aransas, TX

Marbà N, Duarte CM (1994) Growth response of the seagrass Cymodocea nodosa to experimental burial and erosion. Mar Ecol Prog Ser 107:307-311

- Maurer D, Keck RT, Tinsman JC, Leathem WA (1981) Vertical migration and mortality of benthos in dredged material-Part I: Mollusca. Mar Environ Res 4:299-319

> McCormick-Ray J (2005) Historical oyster reef connections to Chesapeake Bay-a framework for consideration. Estuar Coast Shelf Sci 64:119-134

> Meade RH (1982) Sources, sinks, and storage of river sediment in the Atlantic drainage of the United States. J Geol 90:235-252

Meyer DL, Townsend EC, Thayer GW (1997) Stabilization and erosion control value of oyster cultch for intertidal marsh. Restor Ecol 5:93-99

Miller DC, Muir CL, Hauser OA (2002) Detrimental effects of sedimentation on marine benthos: What can be learned from natural processes and rates? Ecol Eng 19:211-232

- Najjar R, Pyke CR, Adams MB, Breitburg D and others (2010) Potential climate change impacts on the Chesapeake Bay. Estuar Coast Shelf Sci 86:1-20

Norris RM (1953) Buried oyster reefs in some Texas bays. J Paleontol 27:569-576

> Orth RJ, Carruthers JB, Dennison WC, Duarte CM and others (2006) A global crisis for seagrass ecosystems. Bioscience 56:987-996

Piazza BP, Banks PD, LaPeyre MK (2005) The potential for created oyster shell reefs as a sustainable shoreline protection strategy in Louisiana. Restor Ecol 13:499-506

> Powers SP, Peterson CH, Grabowski JH, Lenihan HS (2009) Success of constructed oyster reefs in no-harvest sanctuaries: implications for restoration. Mar Ecol Prog Ser 389: 159-170

Pyke CR, Najjar R, Adams MB, Breitburg D and others (2008) Climate change and the Chesapeake Bay: State of the science review and recommendations. Report from the Chesapeake Bay Program Science and Technical Advisory Committee. STAC, Annapolis, MD, http://chesapeake.org/stac/Pubs/climchangereport.pdf

R Core Development Team (2013) R: A language and environment for statistical computing. R Foundation for Statistical Computing, Vienna. www.R-project.org/

- Rodriguez AB, Fodrie FJ, Ridge JT, Lindquist NL and others (2014) Oyster reefs can outpace sea-level rise. Nat Clim Change 4:493-497

Rose CD (1973) Mortality of market-sized oysters (Crassostrea virginica) in the vicinity of a dredging operation. Chesap Sci 14:135-138

Rothschild BJ, Ault JS, Goulletquer P, Héral M (1994) Decline of the Chesapeake Bay oyster population: a century of habitat destruction and overfishing. Mar Ecol Prog Ser 111:29-39

Sallenger AH, Doran KS, Howd PA (2012) Hotspot of accelerated sea-level rise on the Atlantic coast of North America. Nat Clim Change 2:884-888

Sanford LP, Panageotou W, Halka JP (1991) Tidal resuspension of sediments in northern Chesapeake Bay. Mar Geol 97:87-103

Short FT, Neckles HA (1999) The effects of global climate change on seagrasses. Aquat Bot 63:169-196

Shumway SE (1996) Natural environmental factors. In:
Kennedy VS, Newell RIE, Eble AF (eds) The eastern oyster: Crassostrea virginica. Maryland Sea Grant Press, College Park, MD

Smith GF, Bruce DG, Roach EB (2001) Remote acoustic habitat assessment techniques used to characterize the quality and extent of oyster bottom in the Chesapeake Bay. Mar Geod 24:171-189

Southworth M, Mann R (2014) The status of Virginia's public oyster resource, 2013. Molluscan Ecology Program. Virginia Institute of Marine Science, Gloucester Point, VA

Suedel BC, Clarke JU, Wilkens J, Lutz CH, Clarke DG (2014) The effects of a simulated suspended sediment plume on eastern oyster (Crassostrea virginica) survival, growth and condition. Estuar Coast 38:578-589

- Syvitski JPM, Vörösmarty CJ, Kettner AJ, Green P (2005) Impact of humans on the flux of terrestrial sediment to the global coastal ocean. Science 308:376-380

- Taylor J, Bushek D (2008) Intertidal oyster reefs can persist and function in a temperate North American Atlantic estuary. Mar Ecol Prog Ser 361:301-306

Thompson RJ, Newell RIE, Kennedy VS, Mann R (1996) Reproductive processes and early development. In: Kennedy VS, Newell RIE, Eble AF (eds) The eastern oyster: Crassostrea virginica. Maryland Sea Grant Press, College Park, MD

Twichell D, Edmiston I, Andrews B, Stevenson W, Donoghue J, Poore R, Osterman L (2010) Geologic controls on the recent evolution of oyster reefs in Apalachicola Bay and St. George Sound, Florida. Estuar Coast Shelf Sci 88: 385-394

Walton WC, Rikard FS, Chaplin GI, Davis JE, Arias CR, Supan JE (2013) Effects of ploidy and gear on the performance of cultured oysters, Crassostrea virginica: survival, growth, shape, condition index and Vibrio abundances. Aquaculture 414:260-266

> Waycott M, Duarte CM, Carruthers TJB, Orth RJ and others (2009) Accelerating loss of seagrasses across the globe threatens coastal ecosystems. Proc Natl Acad Sci USA 106:12377-12381

> Widdows J, Newell RIE, Mann R (1989) Effects of hypoxia and anoxia on survival, energy, metabolism, and feeding of oyster larvae (Crassostrea virginica, Gmelin). Biol Bull 177:154-166

Widdows J, Brinsley MD, Bowley N, Barett C (1998) A benthic annular flume for in situ measurement of suspension feeding/biodeposition rates and erosion potential of intertidal cohesive sediments. Estuar Coast Shelf Sci 46: 27-38

Wilber DH, Clarke DG (2001) Biological effects of suspended sediments: a review of suspended sediment impacts on fish and shellfish with relation to dredging activities in estuaries. N Am J Fish Manage 21:855-873

> Wilberg MJ, Wiedenmann JR, Robinson JM (2013) Sustainable exploitation and management of autogenic ecosystem engineers: application to oysters in Chesapeake Bay. Ecol Appl 23:766-776

Zimmerman RJ, Minello T, Baumer T, Castiglione M (1989) Oyster reef as habitat for estuarine macrofauna. National Marine Fisheries Service Southeast Fisheries Science Center, Galveston, TX

> Zu Ermgassen PSE, Spalding MD, Blake B, Coen LD and others (2012) Historical ecology with real numbers: past and present extent and biomass of an imperiled estuarine habitat. Proc R Soc Lond B Biol Sci 282:1-8 